\title{
Hyperthermia Increases Neurotoxicity Associated with Novel Methcathinones
}

\author{
Xun Zhou 1,2, Jamal Bouitbir 1,2,3® , Matthias E. Liechti 1,2®) Stephan Krähenbühl ${ }^{1,2,3, * \mathbb{C}}$ \\ and Riccardo V. Mancuso 1,2 (D) \\ 1 Division of Clinical Pharmacology \& Toxicology, University Hospital Basel, 4031 Basel, Switzerland; \\ xun.zhou@unibas.ch (X.Z.); jamal.bouitbir@unibas.ch (J.B.); matthias.liechti@usb.ch (M.E.L.); \\ riccardo.mancuso@unibas.ch (R.V.M.) \\ 2 Department of Biomedicine, University of Basel, 4031 Basel, Switzerland \\ 3 Swiss Centre for Applied Human Toxicology, 4031 Basel, Switzerland \\ * Correspondence: stephan.kraehenbuehl@usb.ch; Tel.: +41-61-265-4715
}

Received: 24 February 2020; Accepted: 9 April 2020; Published: 14 April 2020

\begin{abstract}
Hyperthermia is one of the severe acute adverse effects that can be caused by the ingestion of recreational drugs, such as methcathinones. The effect of hyperthermia on neurotoxicity is currently not known. The primary aim of our study was therefore to investigate the effects of hyperthermia $\left(40.5^{\circ} \mathrm{C}\right)$ on the neurotoxicity of methcathinone $(\mathrm{MC})$, 4-chloromethcathinone (4-CMC), and 4-methylmethcathinone (4-MMC) in SH-SY5Y cells. We found that 4-CMC and 4-MMC were cytotoxic (decrease in cellular ATP and plasma membrane damage) under both hyper- $\left(40.5^{\circ} \mathrm{C}\right)$ and normothermic conditions $\left(37^{\circ} \mathrm{C}\right)$, whereby cells were more sensitive to the toxicants at $40.5^{\circ} \mathrm{C}$. 4-CMC and 4-MMC impaired the function of the mitochondrial electron transport chain and increased mitochondrial formation of reactive oxygen species (ROS) in SH-SY5Y cells, which were accentuated under hyperthermic conditions. Hyperthermia was associated with a rapid expression of the 70 kilodalton heat shock protein (Hsp70), which partially prevented cell death after $6 \mathrm{~h}$ of exposure to the toxicants. After $24 \mathrm{~h}$ of exposure, autophagy was stimulated by the toxicants and by hyperthermia but could only partially prevent cell death. In conclusion, hyperthermic conditions increased the neurotoxic properties of methcathinones despite the stimulation of protective mechanisms. These findings may be important for the understanding of the mechanisms and clinical consequences of the neurotoxicity associated with these compounds.
\end{abstract}

Keywords: autophagy; hyperthermia; methcathinone; mitochondria; neurotoxicity

\section{Introduction}

New psychoactive substances (NPSs) are a broad group of drugs of abuse that are not controlled by classic international drug laws [1]. The abuse of NPSs is a major problem worldwide, since NPSs can elicit serious toxic effects on users [2]. In recent years, several synthetic cathinones, designated as "legal highs", have emerged and their use as recreational drugs has grown rapidly [3]. Structurally, synthetic cathinones are $\beta$-keto-amphetamine derivatives, with pharmacological and toxicological properties similar to amphetamines [3]. Synthetic cathinones, such as methcathinone (MC), 4-chloromethcathinone (4-CMC), and 4-methylmethcathinone (4-MMC, mephedrone) (see Figure S1 for chemical structures), have recently been recognized by the European Monitoring Centre for Drugs and Drug Addiction (EMCDDA) as emerging NPSs [4-6].

Despite clinical studies with and initial use of some synthetic cathinones for the treatment of depression, appetite suppression, or smoking-cessation, none of these compounds have been approved for one of these indications, mainly due to their adverse effect profile [7]. Relevant adverse effects 
reported for synthetic cathinones include anxiety, paranoia, depression, stroke, seizures, hyperthermia, heart failure, liver failure, and even death $[7,8]$.

Hyperthermia, also reported as "overheating", is one of the prominent acute severe adverse effects of stimulant drug abuse, and one of the primary causes of death $[9,10]$. According to clinical case reports, drug-induced hyperthermia can result in many potentially fatal complications, such as hyponatremia, rhabdomyolysis, cerebral edema, disseminated intravascular coagulation, and coma [11]. Drug-induced hyperthermia can be caused by several factors. Most psychostimulant drugs can directly increase metabolic heat production by central and/or peripheral mechanisms as well as decrease heat dissipation $[9,10]$. Several clinical cases of hyperthermia induced by synthetic cathinones have been reported so far [12] and a large number of animal studies have been performed in mice and rats to investigate the effect of these compounds on the body temperature [13]. Polysubstance abuse may contribute to methcathinone-induced hyperthermia. Additionally, a drug that may accidentally or deliberately be used in combination with cathinones is 3,4-methylenedioxymethamphetamine (MDMA), an amphetamine derivative with well-known effects on thermoregulation [9,14]. In addition, environmental effects that users face in dancing clubs where these drugs are usually consumed may contribute as well as to hyperthermia associated with methcathinones and MDMA [15,16].

While the capacity of cathinones and many other recreational drugs to increase the body and brain temperature is well established, the effects of hyperthermia on neurotoxicity associated with these drugs is currently less well known [13]. Barbosa et al. investigated the effect of ecstasy and ecstasy metabolites on SH-SY5Y cells under normothermic $\left(37^{\circ} \mathrm{C}\right)$ and hyperthermic $\left(40^{\circ} \mathrm{C}\right)$ conditions [17]. They found that the metabolites were more toxic than the parent compound and that the toxicity increased with higher temperature. The aim of the current study was to investigate in vitro the role of hyperthermia on methcathinone-induced neurotoxicity using the well-established SH-SY5Y neuronal cell model [18].

\section{Materials and Methods}

\subsection{Chemicals and Cell Culture}

Amphetamine, 4-fluoroamphetamine (4-FA), methcathinone (MC), 4-fluoromethcathinone (4-FMC), 4-chloromethcathinone (4-CMC), 4-methylmethcathinone (4-MMC), and 3,4-methylenedioxymethamphetamine (MDMA) were purchased from Lipomed (Arlesheim, Switzerland). 4-Chloroamphetamine (PCA) was purchased from Cayman Chemical (Ann Arbor, MI, USA). All drugs were racemic hydrochloride salts with an HPLC purity of $>98 \%$. Test drugs were dissolved in dimethyl sulfoxide (DMSO) and stored at $-20^{\circ} \mathrm{C}$. The final DMSO concentration during the experiment was $0.1 \%$.

The SH-SY5Y human neuroblastoma cell line was purchased from European Collection of Authenticated Cell Cultures (RRID:CVCL_0019, ECACC) (Sigma-Aldrich, Buchs, Switzerland). SH-SY5Y cells were cultured in a $5 \% \mathrm{CO}_{2}$ incubator at 37 (normothermic conditions) or $40.5{ }^{\circ} \mathrm{C}$ (hyperthermic conditions) in high glucose Dulbecco's Modified Eagle's Medium (DMEM) (Thermo Fischer Scientific, Basel, Switzerland) containing 15\% heat-inactivated fetal bovine serum (FBS) (Thermo Fischer Scientific, Basel, Switzerland), 2 mM L-glutamine (Thermo Fischer Scientific, Basel, Switzerland), and $1 \mathrm{mM}$ sodium pyruvate (Thermo Fischer Scientific, Basel, Switzerland).

\subsection{Cell Membrane Toxicity}

The release of adenylate kinase (AK) into the cell medium was assessed as a marker to measure plasma membrane integrity. We used the ToxiLight Bioassay Kit (Lonza, Basel, Switzerland) according to the manufacturer's protocol. In brief, SH-SY5Y cells (50,000 cells per well) were seeded into a 96-well Costar polystyrene plate and left to grow overnight. Afterwards, the medium was removed, and the cells were exposed to different concentrations of PCA (from 100 to $1000 \mu \mathrm{M}$ ), amphetamine, 4-FA, MC, 4-FMC, 4-CMC, and 4-MMC (from 200 to $2000 \mu \mathrm{M}$ ). Triton X-100 (0.1\%) was used as a positive control to 
induce cell lysis. MDMA (500 $\mu \mathrm{M}$ and $1000 \mu \mathrm{M})$ was used as a control drug, which is known to induce hyperthermia in vivo [9]. The plate was incubated at 37 and $40.5{ }^{\circ} \mathrm{C}$ in $5 \% \mathrm{CO}_{2}$ and saturated humidity for 6 and $24 \mathrm{~h}$. Then, $20 \mu \mathrm{L}$ of cell supernatant was transferred into a luminescence-compatible 96-well plate followed by the addition of $50 \mu \mathrm{L}$ of AK detection reagent. The plate was incubated at room temperature (RT) for $5 \mathrm{~min}$, and the luminescence was measured with a M200 Pro Infinity plate reader (Tecan, Männedorf, Switzerland). All data were normalized to DMSO 0.1\%-treated cells (control).

\subsection{Intracellular ATP Content}

Changes in the intracellular ATP content were measured using the CellTiter-Glo ${ }^{\circledR}$ kit from Promega (Dübendorf, Switzerland) according to the manufacturer's protocol. SH-SY5Y cells were treated as described above. After 6 and $24 \mathrm{~h}$ of treatment, $80 \mu \mathrm{L}$ of assay buffer was added to each well containing SH-SY5Y cells in $80 \mu \mathrm{L}$ of culture medium. The plate was shaken for $2 \mathrm{~min}$ at $350 \mathrm{rpm}$, followed by 15 min of incubation at RT. The ATP content was determined by luminescence measurement using a M200 Pro Infinity plate reader (Tecan, Männedorf, Switzerland). All data were normalized to DMSO $0.1 \%$-treated cells (control).

\subsection{Mitochondrial Membrane Potential}

The mitochondrial membrane potential $(\Delta \psi \mathrm{m})$ was measured using the JC-10 Mitochondrial Membrane Potential Assay Kit (Abcam, Cambridge, UK) according to the manufacturer's protocol. In healthy cells, JC-10 concentrates in the mitochondrial matrix where it forms red fluorescent aggregates, whereas, in apoptotic and necrotic cells where the $\Delta \psi \mathrm{m}$ decreases, JC-10 diffuses out of mitochondria, changes to a monomeric form, and stains cells with green fluorescence [19]. SH-SY5Y cells were seeded into black Costar 96-well plates at 50,000 cells per well. Upon incubation with different concentrations of the synthetic methcathinones $(200-2000 \mu \mathrm{M})$ at 37 or $40.5^{\circ} \mathrm{C}$ for $24 \mathrm{~h}$, the supernatant was removed and the cells were rinsed with PBS. Then, $50 \mu \mathrm{L}$ of JC-10 dye-loading solution was added to each well and the plate was incubated for $15 \mathrm{~min}$ at $37^{\circ} \mathrm{C}$ and $5 \% \mathrm{CO}_{2}$ with light protection. Carbonyl cyanide-p-trifluoromethoxyphenylhydrazone (FCCP, $100 \mu \mathrm{M})$ was used as a positive control. FCCP is an uncoupler of mitochondrial oxidative phosphorylation and therefore decreases $\Delta \psi \mathrm{m}$ [20]. SH-SY5 cells were exposed to FCCP for $4 \mathrm{~h}$.

The fluorescence was measured using a Tecan M200 Infinite Pro plate reader (Tecan, Männedorf, Switzerland) at $490 / 525 \mathrm{~nm}$ for the aggregates, and at $540 / 590 \mathrm{~nm}$ for monomeric forms. The ratio of the fluorescence intensities between aggregates and monomers was considered as an indicator of $\Delta \psi \mathrm{m}$. Data were normalized to control incubations containing DMSO $0.1 \%$.

\subsection{Mitochondrial Oxygen Consumption}

In order to assess the changes in mitochondrial respiration due to hyperthermia in the presence of test drugs, the mitochondrial oxygen consumption rate (OCR) was measured with a Seahorse XF96 analyzer (Seahorse Biosciences, North Billerica, MA, USA). SH-SY5Y cells were seeded at a density of 50,000 cells per well into XF96 Cell Culture Microplates (Seahorse Biosciences, North Billerica, MA, USA) coated with the cell adhesive Corning ${ }^{\mathrm{TM}}$ Cell-Tak $(22.4 \mu \mathrm{g} / \mathrm{mL})$ (Corning, New York, USA). SH-SY5Y cells were left to grow overnight and then treated with different concentrations of test drugs (200, 500, and $1000 \mu \mathrm{M})$ for $24 \mathrm{~h}$ at 37 and $40.5^{\circ} \mathrm{C}$. Before the measurement, SH-SY5Y cells were rinsed twice with unbuffered DMEM medium ( $4 \mathrm{mM}$ L-glutamate, $1000 \mu \mathrm{M}$ pyruvate, $1 \mathrm{~g} / \mathrm{L}$ glucose, and $63.3 \mathrm{mM}$ sodium chloride, $\mathrm{pH} 7.4$ ) and equilibrated in a $\mathrm{CO}_{2}$-free incubator for $30 \mathrm{~min}$. First, basal oxygen consumption was measured, then the leak respiratory rate after automated injection of an ATP synthase inhibitor (oligomycin $1 \mu \mathrm{M})$. Maximal OCR was determined by adding FCCP $(1 \mu \mathrm{M})$. Finally, the non-mitochondrial respiration rate was obtained by the addition of an electron transport chain complex I inhibitor (rotenone $1 \mu \mathrm{M}$ ). OCR was automatically recorded by the Wave software (Seahorse Biosciences, North Billerica, MA, USA), and data were normalized to the protein content 
determined using the Pierce BCA Protein Assay kit (Thermo Fisher Scientific, Basel, Switzerland). OCR was expressed as $\mathrm{pmol}_{2}$ per minute per $\mathrm{mg}$ of protein.

\subsection{Mitochondrial Superoxide Production}

Mitochondrial superoxide production was assessed using the MitoSOX ${ }^{\mathrm{TM}}$ Red fluorophore probe (Thermo Fisher Scientific, Basel, Switzerland). SH-SY5Y cells were seeded into a black 96-well plate at a density of 50,000 cells per well, treated with the synthetic methcathinones at different concentrations (from 200 to $2000 \mu \mathrm{M}$ ), and incubated for $24 \mathrm{~h}$ at 37 or $40.5^{\circ} \mathrm{C}$. Amiodarone $(50 \mu \mathrm{M})$ was used as a positive control [21]. MDMA (500 and $1000 \mu \mathrm{M})$ was used as a control drug known to induce hyperthermia in vivo [9]. Upon treatment, the medium was removed, and the cells were rinsed with PBS. Next, $100 \mu \mathrm{L}$ of PBS containing MitoSOX reagent $(2.5 \mu \mathrm{M})$ was added to each well and the plate was incubated for $10 \mathrm{~min}$ at $37^{\circ} \mathrm{C}$ with light protection. The fluorescence was measured using a Tecan M200 Infinite Pro plate reader (Tecan, Männedorf, Switzerland) at 510/580 nm. The results were normalized to the protein content quantified by the Pierce BCA Protein Assay kit (Thermo Fisher Scientific, Basel, Switzerland) and to DMSO 0.1\%-treated control cells.

\subsection{Apoptosis}

Apoptosis (early and late apoptosis/necrosis) was determined using the Alexa Fluor ${ }^{\circledR} 488$ annexin V/propidium iodide (PI) staining kit, according to the manufacturer's protocol (Vybrant TM Apoptosis Assay Kit \#2) (Gibco Life Technologies, Paisley, UK) and followed by flow cytometric acquisition using a Cytoflex cytometer (Beckman Coulter, Indianapolis, IN, USA). Briefly, SH-SY5Y cells were seeded into a 48-well plate at a density of 200,000 cells per well and left to grow overnight. The cells were treated with MC, 4-CMC, 4-MMC at 1000 and $2000 \mu \mathrm{M}$, and MDMA at 500 and $1000 \mu \mathrm{M}$, for 6 and for $24 \mathrm{~h}$ at 37 and $40.5^{\circ} \mathrm{C} . \mathrm{H}_{2} \mathrm{O}_{2}(500 \mu \mathrm{M})$ was used as a positive control for apoptosis [22]. The 6-h incubation time was selected to focus on the early apoptosis phase rather than on the necrosis. On the day of measurement, the cells were transferred into a V-well plate, pelleted, and washed twice with PBS. Then, $100 \mu \mathrm{L}$ of $1 \times$ Annexin-Binding Buffer containing $5 \mu \mathrm{L}$ of Alexa Fluor ${ }^{\circledR} 488$ annexin $\mathrm{V}, 1 \mu \mathrm{L}$ of PI $(100 \mu \mathrm{g} / \mathrm{mL})$, and $0.5 \mu \mathrm{L}$ of anti-CD29-APC (RRID:AB_314323, clone TS2/16) (BioLegend, San Diego, CA, USA) was added to each well. CD29 is a member of the integrin family expressed on the membrane of SH-SY5Y cells [23]. Thereafter, the plate was incubated at $4{ }^{\circ} \mathrm{C}$ for 15 min with light protection. For the flow cytometry gating strategy, singlets were first identified by a forward scatter area (FSC-A) and forward scatter height (FSC-H) gate, and then by an FSC-A and side scatter area (SSC-A) gate. Intact SH-SY5Y cells were distinguished from cell debris by staining with anti-CD29-APC in a FL5-A/SCC-A dot plot. Samples were analyzed using FlowJo software, Tree Star (RRID:SCR_008520) (Ashland, OR, USA).

\subsection{Western Blotting}

SH-SY5Y cells were seeded into 6-well plates and left to grow overnight. For the assessment of Hsp70, caspase 3, LC3 I, and LC3 II, cells were treated with methcathinones (MC, 4-CMC, and $4-\mathrm{MMC})$ at the concentrations of 1000 and $2000 \mu \mathrm{M}$, and with MDMA at 500 and $1000 \mu \mathrm{M}$ at 37 or $40.5^{\circ} \mathrm{C}$. Concanamycin A (100 nM) and bafilomycin A (100 nM) (Tocris Bioscience, Abingdon, UK) were used as positive controls for the inhibition of autophagy [24]. Hsp70 and caspase 3 were quantified after $6 \mathrm{~h}$ of incubation, LC3 I and LC3 II were quantified after $24 \mathrm{~h}$ of incubation. Upon treatment, cells were lysed using radioimmunoprecipitation assay (RIPA) buffer with complete protease inhibitor (Roche Diagnostics, Mannheim, Germany) on ice for $15 \mathrm{~min}$ and then centrifuged to obtain protein samples. Following the collection of supernatants, BCA Pierce assay was used to quantify the protein concentration of each sample. Afterwards, a total of $18 \mu \mathrm{g}$ protein per sample was loaded and run onto a $4-12 \%$ SDS-PAGE gel and then electroblotted onto a nitrocellulose membrane. The membrane was blocked with $5 \%$ non-fat milk in TBST buffer $(4 \mathrm{mM}$ Tris base saline containing $0.1 \%$ Tween-20, pH 7.5) for $1 \mathrm{~h}$ at RT, and then incubated with primary antibody anti-heat shock protein 70 
(Hsp70, 1:1000 dilution, ab2787 Abcam, RRID:AB_303300, Cambridge, UK), anti-cleaved caspase 3 (1:500 dilution, ab32042, RRID:AB_725947, Abcam, Cambridge, UK), anti-caspase 3 (1:500 dilution, 8G10, RRID:AB_2069872, Cell Signaling Technology, Danvers, USA), anti-LC3 I/II (1:1000 dilution, 12741s, RRID:AB_2617131, Cell Signaling Technology, Danvers, USA), and anti-glyceraldehyde 3-phosphate dehydrogenase (GAPDH) (1:5000 dilution, sc-365062, RRID:AB_10847862, Santa Cruz Biotechnology, Dallas, USA) overnight at $4{ }^{\circ} \mathrm{C}$. After washing three times with TBST buffer, the membrane was incubated with a secondary antibody (1:2000 dilution, Santa Cruz Biotechnology, USA) for $1 \mathrm{~h}$ at RT. Then, signals were developed by the enhanced chemiluminescence (ECL) kit (Bio-Rad Laboratories, Hercules, USA). Protein expression was quantified by the Fusion Pulse TS device (Vilber Lourmat, Oberschwaben, Germany).

\subsection{Fluorescence Microscopy with Acridine Orange Staining}

Acidic vesicular organelles (AVOs) are autolysosomes and autophagosomes and can be measured as markers of the late autophagic process $[25,26]$. To detect AVOs, cells were stained with acridine orange (AO) according to published protocols $[25,26]$. AO is a lysosomotropic dye, its fluorescence emission is $\mathrm{pH}$ dependent, green at neutral $\mathrm{pH}$ and bright yellow to red within acidic organelles $[25,26]$. SH-SY5Y cells were seeded into ibiTreat $\mu$-Slide (Vitaris, Baar, Switzerland) and exposed to $1000 \mu \mathrm{M}$ of the synthetic methcathinones for $24 \mathrm{~h}$ at $37^{\circ} \mathrm{C}$ or $40.5^{\circ} \mathrm{C}$. Then, the cell culture medium was replaced by AO staining solution $(0.5 \mu \mathrm{g} / \mathrm{mL}$ acridine orange in culture medium), and the $\mu$-Slide was incubated for $20 \mathrm{~min}$ at $37^{\circ} \mathrm{C}$ with light protection. The samples were rinsed three times with pre-warmed medium and pictures were acquired by an Olympus IX83 microscope (Olympus, Shinjuku, Japan).

\subsection{Flow Cytometry with Acridine Orange Staining}

To quantify the formation of AVOs, we detected the intensity of AO fluorescence by flow cytometry. AVOs stained with AO emit red fluorescence (FL3-A, 690/50 nm BP); the increase in the intensity of red fluorescence (AO+ events) is proportional to the volume and number of AVOs [25,26]. SH-SY5Y cells were seeded into a 48-well plate at a density of 200,000 cells per well and left to grow overnight. Cells were treated with MC, 4-CMC, and 4-MMC at 1000 and $2000 \mu \mathrm{M}$, and MDMA at 500 and $1000 \mu \mathrm{M}$, for $24 \mathrm{~h}$, at 37 or $40.5^{\circ} \mathrm{C}$. On the day of measurement, SH-SY5Y cells were transferred and pelleted into a V-well plate, then washed twice with PBS. Afterwards, the cells were incubated with $100 \mu \mathrm{L}$ of AO staining solution $\left(0.5 \mu \mathrm{g} / \mathrm{mL}\right.$ in PBS) for $20 \mathrm{~min}$ at $37^{\circ} \mathrm{C}$ with light protection. SH-SY5Y cells were analyzed with a CytoFLEX flow cytometer (Beckman Coulter, IN, USA). For the flow cytometry gating strategy, singlets were first identified by an FSC-A/FSC-H gate, and then by an FSC-A/SSC-A gate. $\mathrm{AO}+$ cells were identified in an SSC-A/FL3-A dot plot, in comparison to DMSO 0.1\%-treated cells (control). Results were analyzed using the FlowJo software (Tree Star, Ashland, OR, USA).

\subsection{Statistics}

Experimental data are presented as the mean \pm SEM of at least five independent experiments. Statistical comparisons were performed with one-way ANOVA followed by $t$-tests. Statistical significance was considered at $P \leq 0.05$. GraphPad Prism 8.3.0 (RRID:SCR_002798) (GraphPad Software, La Jolla, CA, USA) was used for all statistical analyses.

\section{Results}

\subsection{Cell Membrane Integrity and ATP Content}

In order to obtain an overview of the effect of hyperthermia on amphetamine- and methcathinone-induced neurotoxicity, we first determined the release of $\mathrm{AK}$ and the intracellular ATP content in SH-SY5Y after $24 \mathrm{~h}$ of drug exposure under normothermic $\left(37^{\circ} \mathrm{C}\right)$ and hyperthermic conditions $\left(40.5^{\circ} \mathrm{C}\right)$. AK release is commonly used as a marker of cell membrane integrity, whereas the intracellular ATP content represents a marker of energy metabolism. SH-SY5Y cells were exposed 
to increasing concentrations of amphetamine, 4-fluoroamphetamine (4-FA), 4-chloroamphetamine (PCA), methcathinone (MC), 4-fluoromethcathinone (4-FMC), 4-chloromethcathinone (4-CMC), and 4-methylmethcathinone (4-MMC) (see Figure S1 for chemical structures). MDMA was also included due its widespread use and its known effects on body temperature.

As shown in Figure 1 for methcathinones and MDMA and in Figure S2 for the amphetamines, all of these compounds were membrane toxic and decreased the intracellular ATP content in a concentration-dependent manner. Exceptions were MC and 4-FMC, which did not show any significant toxicity up to $2000 \mu \mathrm{M}$ (Figure 1). 4-FA and PCA were membrane toxic starting at 1000 and $500 \mu \mathrm{M}$, respectively, at both temperatures investigated (Figure S2A), whereas 4-CMC, 4-MMC, and MDMA were significantly more toxic at $40.5^{\circ} \mathrm{C}$, with membrane toxicity starting at $1000 \mu \mathrm{M}$ at this temperature (Figure 1A).
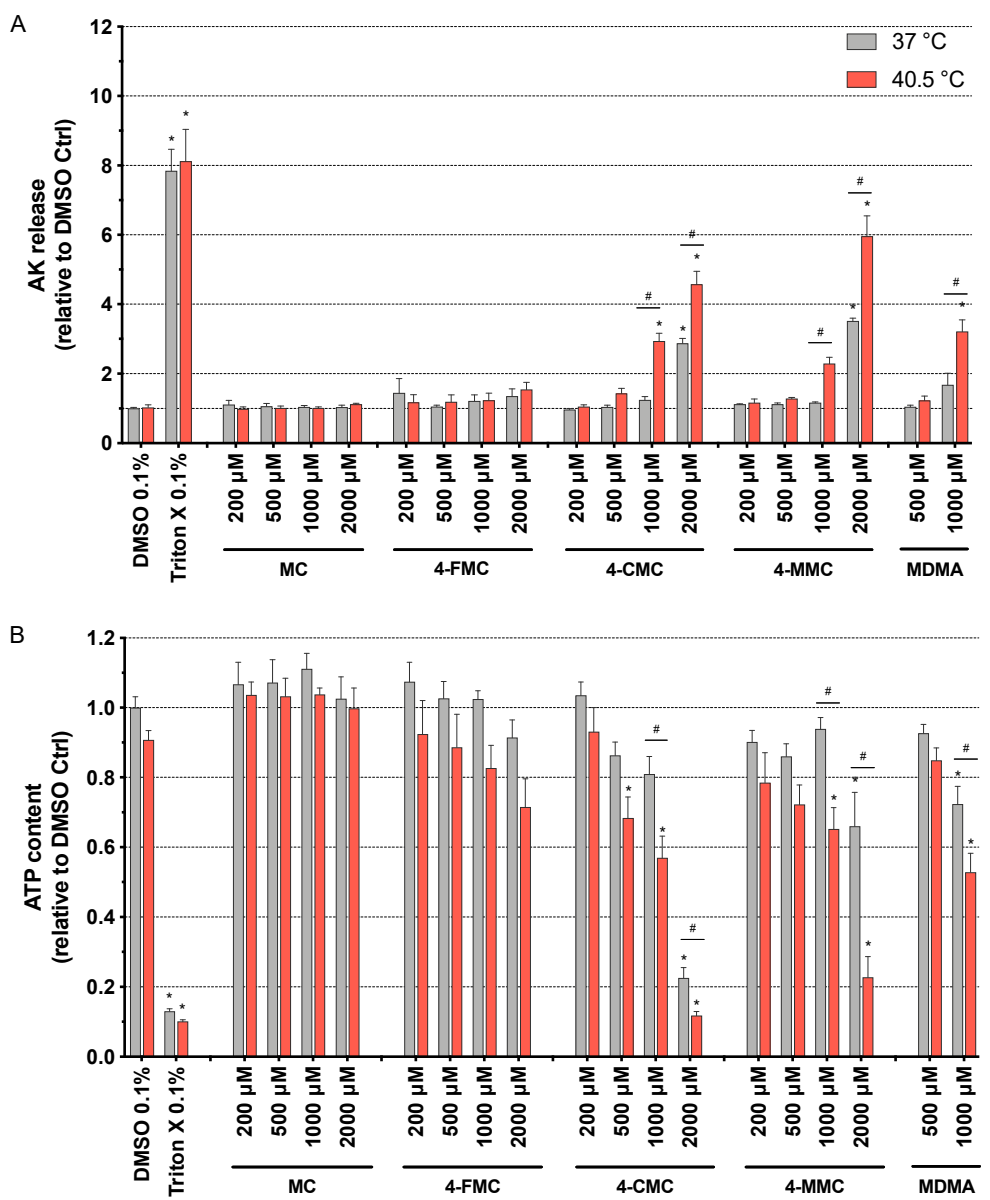

Figure 1. (A) Plasma membrane integrity and (B) intracellular ATP content assessed in SH-SY5Y cells after $24 \mathrm{~h}$ of exposure at 37 and $40.5{ }^{\circ} \mathrm{C}$ to methcathinone (MC), 4-fluoromethcathinone (4-FMC), 4-chloromethcathinone (4-CMC), 4-methylmethcathinone (4-MMC) (200-2000 $\mu \mathrm{M})$, and 3,4-methylenedioxymethamphetamine (MDMA) (500 and $1000 \mu \mathrm{M})$. Dimethyl sulfoxide (DMSO) and Triton $\mathrm{X}$ were used as negative and positive controls, respectively. Data are expressed relative to the DMSO control as the mean \pm SEM of eight independent experiments. Statistical comparisons were performed with one-way ANOVA followed by $t$-tests $\left({ }^{*} P \leq 0.05\right.$ versus control at the same temperature; ${ }^{\#} P \leq 0.05$ versus the same concentration at a different temperature).

The intracellular ATP content in SH-SY5Y cells started to decrease at $2000 \mu \mathrm{M}$ for 4-FA, 4-CMC, and 4-MMC, and at $1000 \mu \mathrm{M}$ for MDMA at normothermic conditions, whereas at $40.5^{\circ} \mathrm{C}$, it started to decrease at $2000 \mu \mathrm{M}$ for amphetamine; $1000 \mu \mathrm{M}$ for 4-FA, MDMA, and 4-MMC; at $200 \mu \mathrm{M}$ for PCA; and at $500 \mu \mathrm{M}$ for 4-CMC (Figure 1B and Figure S2B). 4-FA, 4-CMC, 4-MMC, and MDMA were significantly 
more toxic under hyperthermic conditions (Figure 1B and Figure S2B), in line with the findings of the AK assessment experiments. Moreover, the drugs investigated showed a more pronounced toxicity regarding the decrease in the intracellular ATP content when compared to membrane toxicity, a pattern suggesting mitochondrial toxicity (Table S1).

Based on these first screenings, we decided to investigate the effect of hyperthermia on the neurotoxicity associated with the synthetic methcathinones MC, 4-CMC, and 4-MMC in more detail.

\subsection{Mitochondrial Membrane Potential}

In order to understand the mechanism of temperature-increased mitochondrial toxicity, we determined the $\Delta \psi \mathrm{m}$ by staining SH-SY 55 cells with the JC-10 dye [21]. Our data indicated that MC did not change the $\Delta \psi \mathrm{m}$ significantly up to $2000 \mu \mathrm{M}$ (Figure S3A). Similarly, MDMA was associated with a numeric drop in the $\Delta \psi \mathrm{m}$ but without reaching statistical significance (Figure S3D). In contrast, 4-CMC and 4-MMC decreased the $\Delta \psi \mathrm{m}$ in a concentration-dependent manner at both temperature conditions (Figure S3B and S3C), reaching statistical significance at 2000 and $1000 \mu \mathrm{M}$, respectively. In contrast to AK release and ATP depletion, the $\Delta \psi \mathrm{m}$ did not show a more accentuated decrease at $40.5^{\circ} \mathrm{C}$ compared to $37^{\circ} \mathrm{C}$.

\subsection{Mitochondrial Oxygen Consumption}

The observed decrease in intracellular ATP and $\Delta \psi \mathrm{m}$ could be caused by impaired mitochondrial function. We therefore assessed the oxygen consumption rate (OCR) by exposing SH-SY5Y cells for $24 \mathrm{~h}$ at 37 and $40.5^{\circ} \mathrm{C}$ to the test compounds using a Seahorse XF96 analyzer. While MC was not toxic, 4-CMC $(1000 \mu \mathrm{M}), 4-\mathrm{MMC}(1000 \mu \mathrm{M})$, and MDMA $(500 \mu \mathrm{M})$ significantly decreased mitochondrial basal and FCCP-stimulated respiration at $37^{\circ} \mathrm{C}$ (Figure 2). In comparison, at $40.5{ }^{\circ} \mathrm{C}$, all compounds investigated started to be toxic already at $200 \mu \mathrm{M}$ for both basal and FCCP-stimulated respiration (Figure 2). We also recorded the leak respiration, which is the cellular uptake of oxygen in the presence of the $\mathrm{F}_{1} \mathrm{~F}_{0}$-ATP synthase inhibitor oligomycin. An increase in the leak respiration would indicate uncoupling of oxidative phosphorylation. Since none of the compounds investigated stimulated leak respiration, we can exclude uncoupling as a reason for the observed decrease in $\Delta \psi \mathrm{m}$.
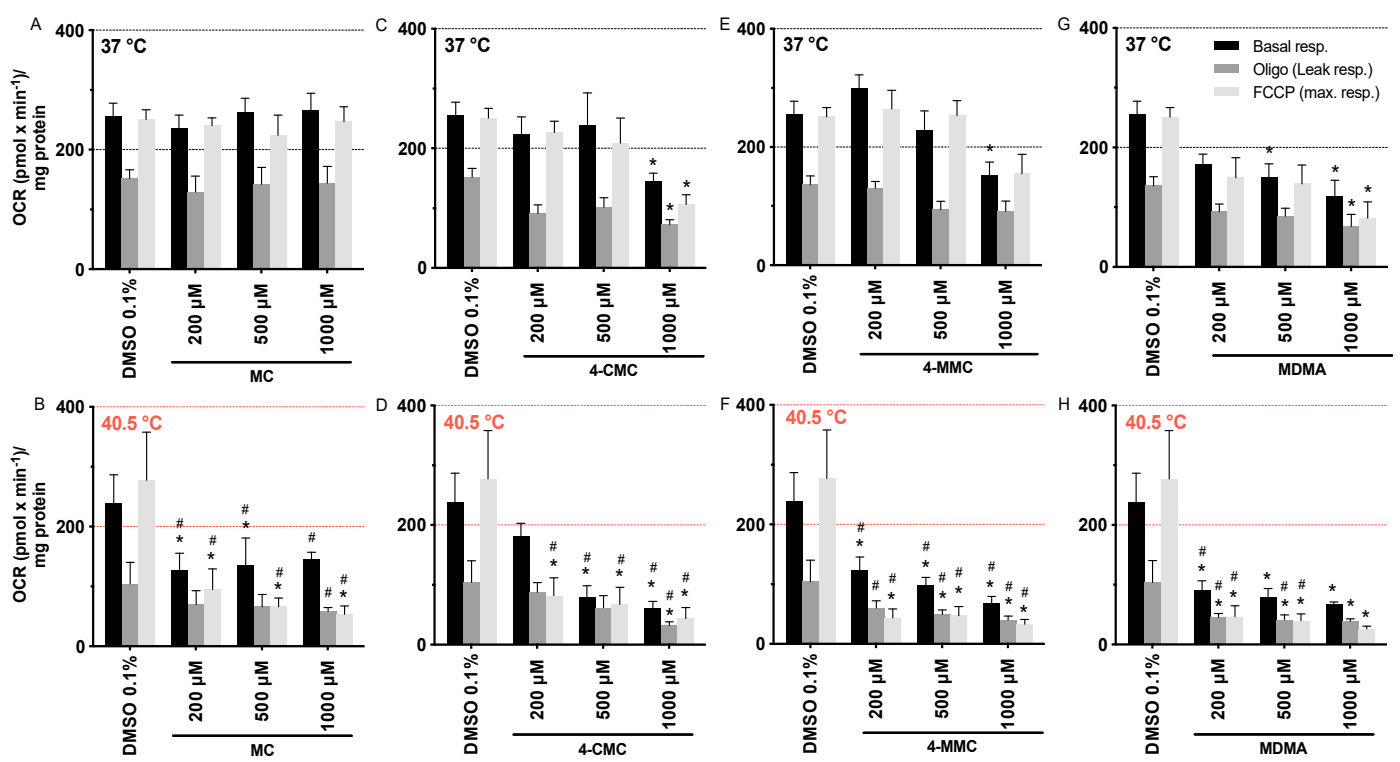

Figure 2. Oxygen consumption rate of SH-SY5Y cells at 37 and $40.5^{\circ} \mathrm{C}$ expressed as basal, leak, and maximal respiration. SH-SY5Y cells were exposed for $24 \mathrm{~h}$ to $(\mathbf{A}, \mathbf{B}) \mathrm{MC},(\mathbf{C}, \mathbf{D})$ 4-CMC (E,F) 4-MMC, and $(\mathbf{G}, \mathbf{H})$ MDMA. Data are expressed as mean \pm SEM of eight independent experiments. Statistical comparisons were performed with one-way ANOVA followed by $t$-tests $\left({ }^{*} P \leq 0.05\right.$ versus control at the same temperature; ${ }^{\#} P \leq 0.05$ versus the same concentration at a different temperature). 
In contrast to the effect on the mitochondrial membrane potential, these data showed that hyperthermic conditions clearly increased the mitochondrial toxicity of MC, 4-CMC, 4-MMC, and MDMA. Furthermore, halogenation and methylation in the $p$-position increased the toxicity of the methcathinones in comparison to hydrogen in this position.

\subsection{Mitochondrial Superoxide Production}

To further investigate the potential involvement of mitochondria in the observed toxicity, we determined the mitochondrial ROS production. The inhibition of complex I and III of the electron transport chain can increase the production of mitochondrial superoxide [27,28]. Mitochondrial ROS were measured in SH-SY5Y cells exposed to methcathinones for $24 \mathrm{~h}$ at 37 and at $40.5^{\circ} \mathrm{C}$. Concerning normothermic conditions, only 4-CMC showed a significant increase of the mitochondrial ROS content, which started at $2000 \mu \mathrm{M}$. At $40.5^{\circ} \mathrm{C}$, the superoxide anion content increased significantly starting at $2000 \mu \mathrm{M}$ for MC, and at $1000 \mu \mathrm{M}$ for 4-CMC, 4-MMC, and MDMA (Figure 3).

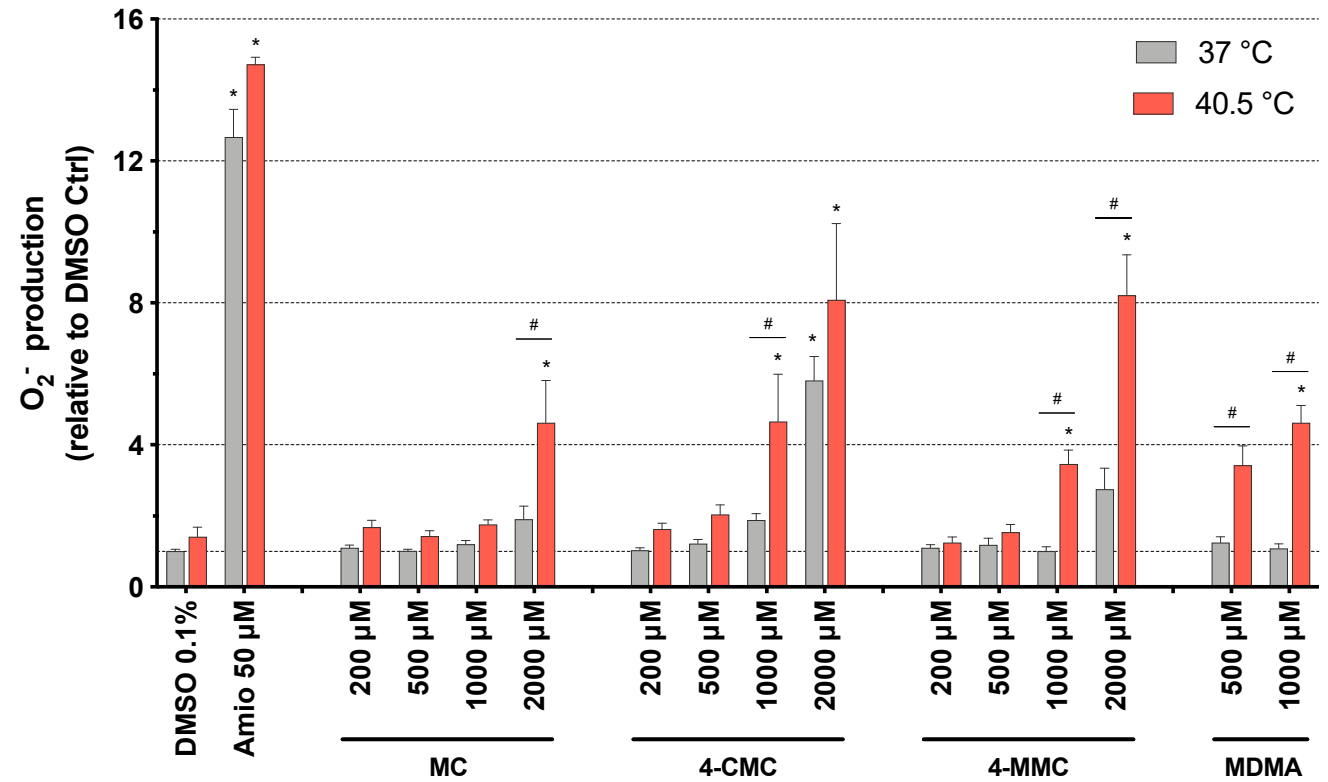

Figure 3. Mitochondrial superoxide production in SH-SY5Y cells at 37 and $40.5^{\circ} \mathrm{C}$ after $24 \mathrm{~h}$ of exposure to MC, 4-CMC, 4-MMC (200-2000 $\mu \mathrm{M})$, and MDMA (500 and $1000 \mu \mathrm{M})$. DMSO and amiodarone were used as negative and positive controls, respectively. Data are expressed relative to DMSO control as mean \pm SEM of six independent experiments run in quadruplicate. Statistical comparisons were performed with one-way ANOVA followed by $t$-tests $\left({ }^{*} P \leq 0.05\right.$ versus control at the same temperature; ${ }^{\#} P \leq 0.05$ versus the same concentration at a different temperature).

\subsection{Cell Death Mechanisms}

Inhibition of oxidative phosphorylation with a decrease in the cellular ATP content and intracellular accumulation of ROS could initiate cell death mechanisms, such as apoptosis and/or necrosis [29]. To clarify whether hyperthermia can affect such events in drug-treated SH-SY5Y cells, we analyzed the proportion of apoptotic and necrotic cells after treatment with test compounds at 37 and $40.5^{\circ} \mathrm{C}$ for 6 and $24 \mathrm{~h}$.

As expected, $\mathrm{H}_{2} \mathrm{O}_{2}$ at $0.5 \mu \mathrm{M}$ increased the number of apoptotic and necrotic cells at both temperatures (Figure $4 \mathrm{~A}$ ). At $37^{\circ} \mathrm{C}$, after $6 \mathrm{~h}$ of incubation, 4-CMC increased the percentage of apoptotic cells significantly, starting at $1000 \mu \mathrm{M}$ (Figure 4A). In comparison, the other compounds tested increased the percentage of apoptotic cells only numerically, without reaching statistical significance. 4-CMC and 4-MMC increased the percentage of necrotic cells starting at 1000 and $2000 \mu \mathrm{M}$, respectively, and MDMA starting at $1000 \mu \mathrm{M}$. Similar results were obtained for caspase 3 activation at 
$37^{\circ} \mathrm{C}$ (Figure 4B). 4-CMC and 4-MMC increased caspase 3 cleavage starting at $1000 \mu \mathrm{M}$, whereas the other compounds tested increased caspase 3 cleavage only numerically. In comparison, at $40.5^{\circ} \mathrm{C}$, the effect of the compounds investigated on the percentage of apoptotic cells (Figure 4A) and caspase 3 cleavage (Figure $4 \mathrm{~B}$ ) was less accentuated than at $37^{\circ} \mathrm{C}$. 4-CMC induced apoptosis, necrosis, and caspase 3 cleavage at $2000 \mu \mathrm{M}$, whereas the other compounds were not associated with significant increases in the induction of apoptosis, necrosis, or caspase 3 cleavage up to $2000 \mu \mathrm{M}$. After $24 \mathrm{~h}$ of incubation at $37^{\circ} \mathrm{C}$, none of the substances tested induced apoptosis, but 4-CMC and 4-MMC induced necrosis starting at $2000 \mu \mathrm{M}$ (Figure S4). At $40.5^{\circ} \mathrm{C}$, the picture was not different from $37^{\circ} \mathrm{C}$, but the extent of necrosis was numerically more accentuated.

A

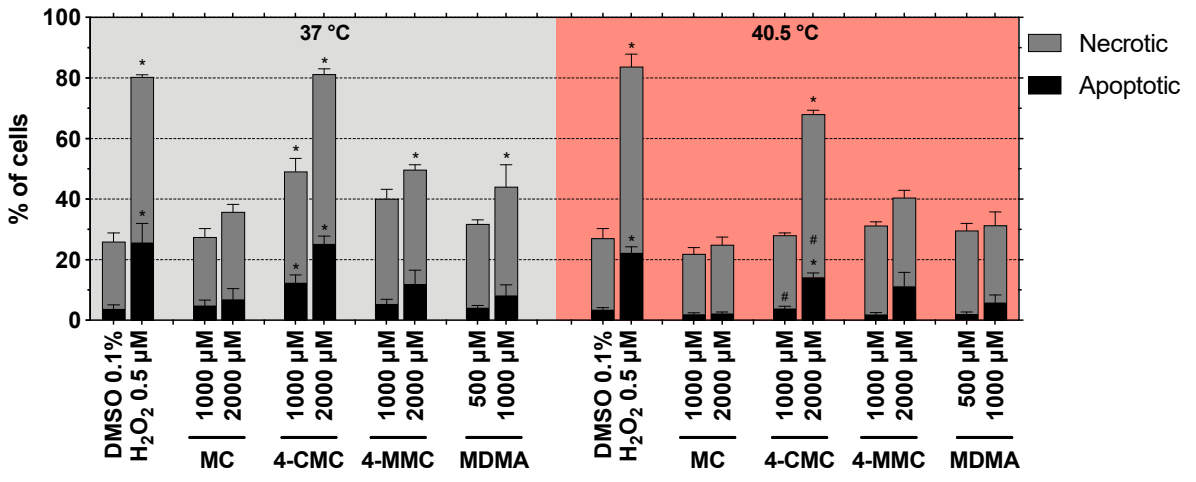

B

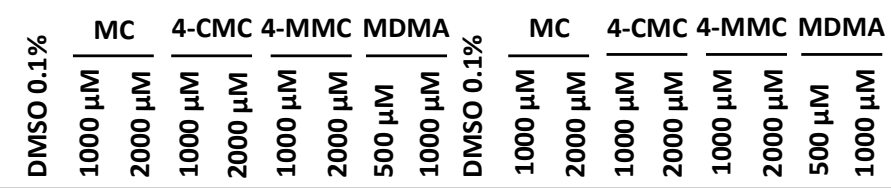

Caspase 3

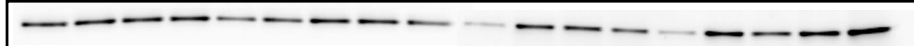

Cleaved

Caspase 3
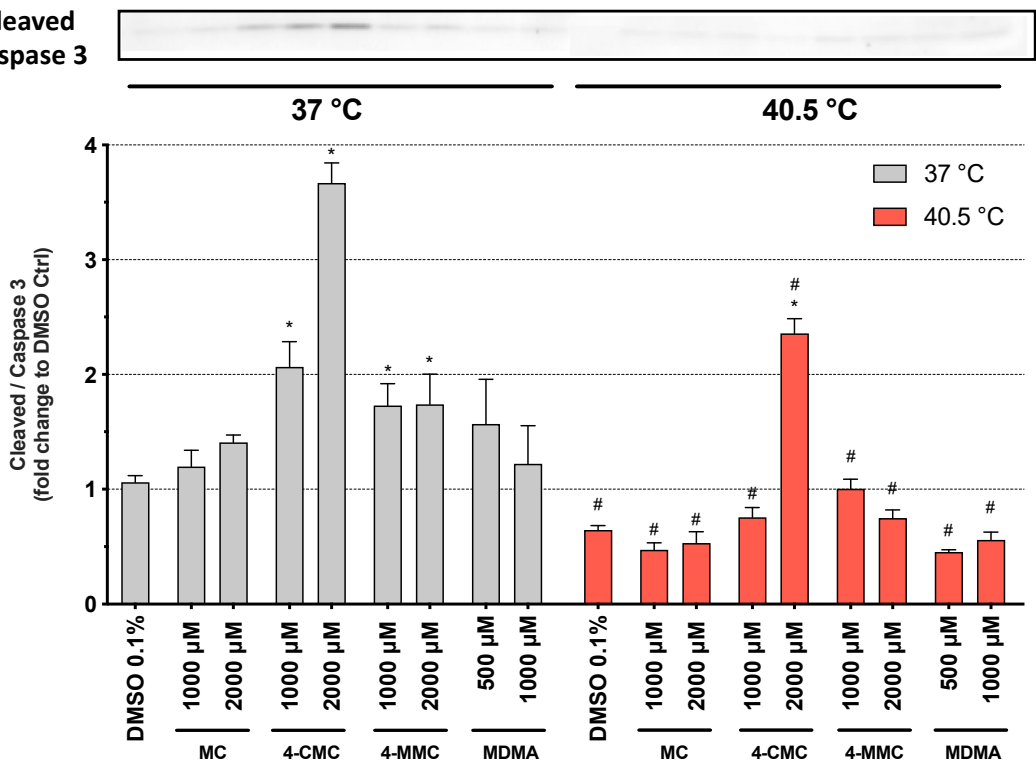

34 kDa

17 kDa

Figure 4. Mechanisms of cell death after $6 \mathrm{~h}$ of exposure at 37 and $40.5^{\circ} \mathrm{C}$ to $\mathrm{MC}, 4-\mathrm{CMC}$, 4-MMC (1000 and $2000 \mu \mathrm{M}$ ), and MDMA (500 and $1000 \mu \mathrm{M}$ ). DMSO and $\mathrm{H}_{2} \mathrm{O}_{2}$ were used as negative and positive controls, respectively. (A) Percentage of necrotic and apoptotic cells. (B) Activation of caspase 3. Data are expressed as mean \pm SEM of six independent experiments. Statistical comparisons were performed with one-way ANOVA followed by $t$-tests $\left({ }^{*} P \leq 0.05\right.$ versus control at the same temperature; ${ }^{\#} P \leq 0.05$ versus the same concentration at a different temperature). 
The data suggested a shift from apoptosis to necrosis at the higher temperature and with longer incubation. In order to obtain a better understanding of this shift, we also determined the AK release and ATP content in the presence of the methcathinone derivatives after $6 \mathrm{~h}$ of incubation (Figure S5). The ATP content dropped, and the AK release increased only at the highest 4-CMC concentrations at both temperatures investigated, which is compatible with the increase in cell necrosis observed with this compound.

To better understand the effects of hyperthermia on the cell death pathways, we measured the expression of Hsp70 protein in SH-SY5Y cells after $6 \mathrm{~h}$ of exposure to the synthetic methcathinones. Hsp70 are a family of proteins, which protect the cells from stress by helping cellular proteins to retain their native conformation or to regain their function after misfolding due to an increased temperature. Hsp70 proteins are usually upregulated by heat stress and toxic chemicals [30]. As expected, Hsp70 expression was significantly increased at $40.5^{\circ} \mathrm{C}$ compared to $37^{\circ} \mathrm{C}$ for all compounds tested as well as for DMSO-treated control cells (Figure 5). In comparison to control incubations, the compounds investigated did not influence Hsp70 expression at 37 or $40.5^{\circ} \mathrm{C}$.

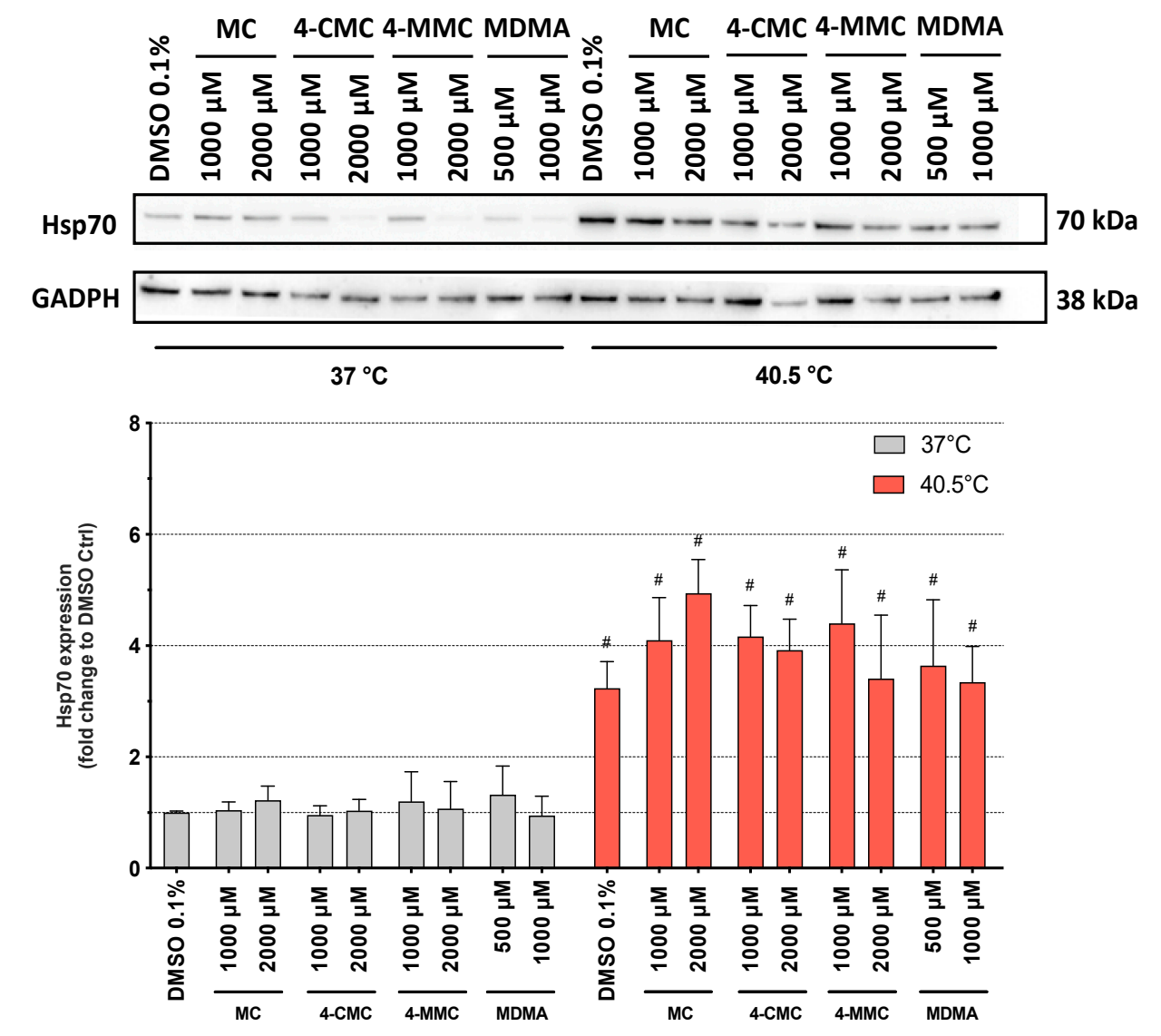

Figure 5. Expression of 70 kilodalton heat shock protein (Hsp70) in SH-SY5Y cells after $6 \mathrm{~h}$ of exposure at 37 and $40.5^{\circ} \mathrm{C}$ to $\mathrm{MC}, 4-\mathrm{CMC}$, 4-MMC (200-2000 $\left.\mu \mathrm{M}\right)$, and MDMA (500 and $\left.1000 \mu \mathrm{M}\right)$. Data are expressed relative to the DMSO control as mean \pm SEM of six independent experiments. Statistical comparisons were performed with one-way ANOVA followed by $t$-tests ( ${ }^{\#} P \leq 0.05$ versus the same concentration at a different temperature).

\subsection{Detection of Autophagy}

Autophagy is a physiological catabolic process used by most cells to remove misfolded proteins or entire organelles in order to maintain proteo- and homeostasis. It is triggered mainly by starvation, cell insults, and DNA damage [31]. Hyperthermic conditions, exposure to mitochondrial toxicants, and cellular ROS accumulation can generate misfolded proteins, which can affect the cellular metabolism [32]. 
In order to explore whether hyperthermia and/or methcathinones can promote autophagy in SH-SY5Y cells, we analyzed the expression of autophagy-related protein microtubule-associated protein 1A/1B-light chain 3 (LC3) by Western blots [25]. LC3 is a component of the autophagosome membranes in mammalian cells, and it is a validated marker for the assessment of early autophagy [33]. During the first phase of autophagy, the cytosolic form of LC3 (LC3 I) is cleaved and conjugated with phosphatidylethanolamine to form LC3 II, which is then translocated into autophagosome membranes. An increase in the LC3 II/LC3 I ratio therefore reflects autophagosome formation [34]. SH-SY5Y cells were exposed at 37 and $40.5^{\circ} \mathrm{C}$ to $\mathrm{MC}, 4-\mathrm{CMC}$, 4-MMC (1000 and $\left.2000 \mu \mathrm{M}\right)$, and MDMA (500 and $1000 \mu \mathrm{M})$. After $24 \mathrm{~h}$ of incubation at $37^{\circ} \mathrm{C}$, all test compounds showed a concentration-dependent increase in the LC3 II/LC3 I ratio compared to control conditions, which reached statistical significance for $2000 \mu \mathrm{M} 4-\mathrm{CMC}$ and for $2000 \mu \mathrm{M}$ 4-MMC (Figure 6). Under hyperthermic conditions, the effect of the test compounds on the LC3 II/LC3 I ratio was similar but more accentuated for 4-CMC and 4-MMC as compared to $37^{\circ} \mathrm{C}$.
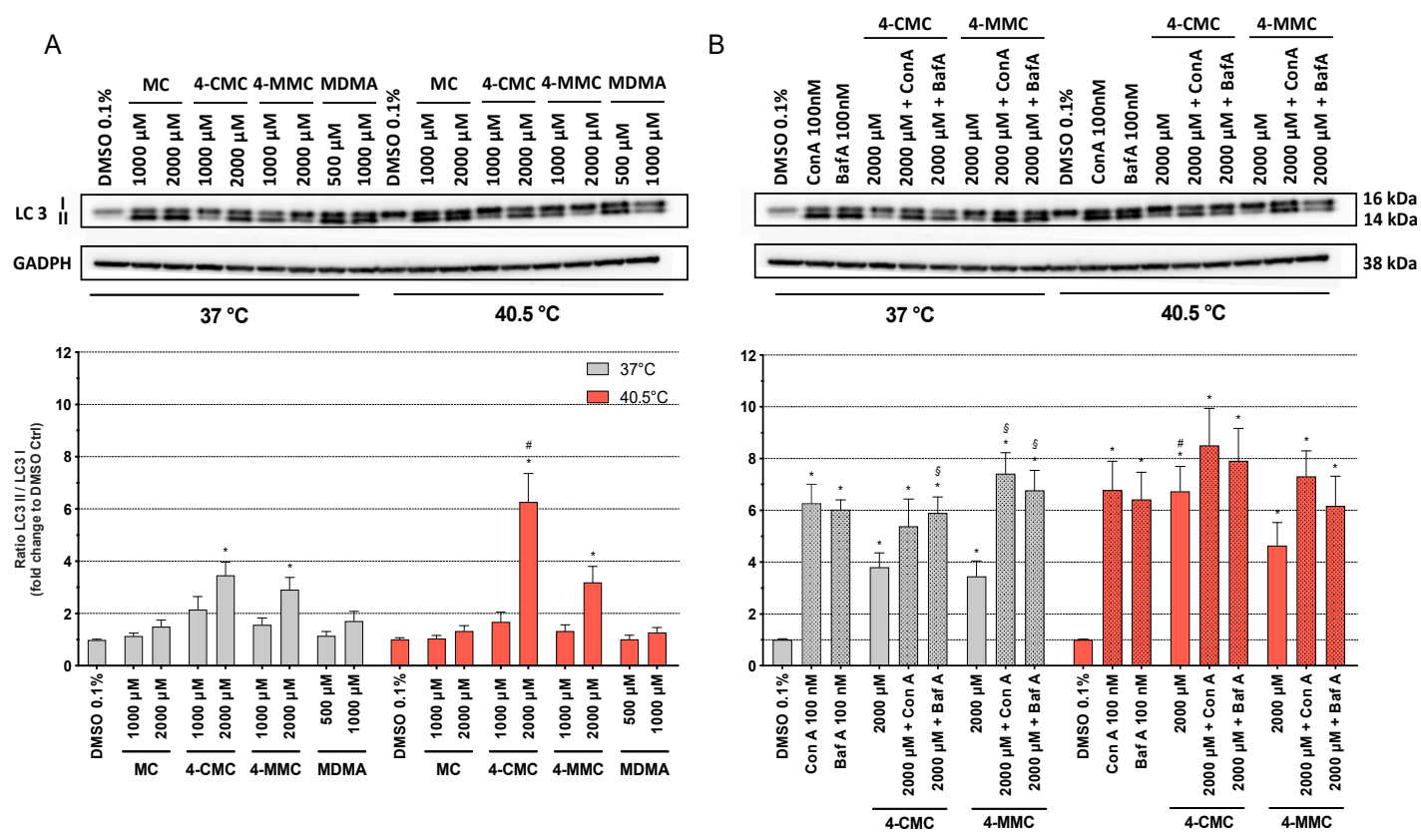

Figure 6. Protein expression of microtubule-associated protein 1A/1B-light chain 3 (LC3) I and LC3 II in SH-SY5Y cells after $24 \mathrm{~h}$ of exposure at 37 and $40.5^{\circ} \mathrm{C}$ to (A) MC, 4-CMC, 4-MMC (200-2000 $\left.\mu \mathrm{M}\right)$, and MDMA (500 and $1000 \mu \mathrm{M}$ ) and (B) in the presence of the autophagy inhibitors concanamycin A (100 nM) and bafilomycin A (100 nM). Data are expressed as the ratio of LC3 II/LC3 I relative to the DMSO control of six independent experiments. Statistical comparisons were performed with one-way ANOVA followed by paired $t$-test $\left({ }^{*} P \leq 0.05\right.$ versus DMSO control at the same temperature; ${ }^{\#} P \leq 0.05$ versus the same concentration at a different temperature; ${ }^{\S} P \leq 0.05$ versus incubations containing 4-CMC or 4-MMC without concanamycin A or bafilomycin A).

In order to investigate whether the observed increase in the LC3 II/LC3 I ratio in the presence of 4-CMC and 4-MMC was due to increased phagosome formation or decreased degradation, we investigated the effect of the two autophagy inhibitors concanamycin A and bafilomycin A on the LC3 II/LC3 I ratio. Concanamycin A and bafilomycin A impair the fusion of autophagosomes and lysosomes by inhibiting the vacuolar $\mathrm{H}^{+}$ATPase and therefore the acidification of organelles, which increases LC3 II expression [24]. As shown in Figure 6A, in the absence of concanamycin A and bafilomycin A, treatment with $2000 \mu \mathrm{M}$ 4-CMC or 4-MMC significantly increased the LC3 II/LC3 I ratio both at 37 and $40.5^{\circ} \mathrm{C}$ compared to control incubations, with $40.5^{\circ} \mathrm{C}$ being more effective than $37^{\circ} \mathrm{C}$. As shown in Figure 6B, as expected, concanamycin A and bafilomycin A increased the LC3 II/LC3 I ratio at both temperatures compared to the DMSO control. At $37^{\circ} \mathrm{C}$, concanamycin A and bafilomycin 
A increased the LC3 II/LC3 I ratio in the presence of 4-CMC or 4-MMC compared to the respective control incubations (2000 $\mu \mathrm{M} 4$-CMC or 4-MMC). At $40.5^{\circ} \mathrm{C}$, this effect was less prominent and did not reach statistical significance. Importantly, the LC3 II/LC3 I ratios of incubations containing only concanamycin A or bafilomycin A and of incubations containing concanamycin A or bafilomycin A in combination with 4-CMC or 4-MMC were not different at both temperatures. Since concanamycin A and bafilomycin A block autosome degradation, the LC3 II/LC3 I ratio in the presence of these inhibitors reflects autophagosome formation, which was obviously not different between incubations containing only concanamycin A or bafilomycin A and incubations containing concanamycin A or bafilomycin A in combination with 4-CMC or 4-MMC. The results therefore suggest that the observed increase in the LC3 II/LC3 I ratio in the presence of 4-CMC and 4-MMC reflects impaired autophagosome degradation and not formation.

To further study the autophagy, we assessed the formation of acidic vesicular organelles (AVOs) [25], which is a hallmark of late autophagy [26]. Microscopic analysis of SH-SY5Y cells exposed for $24 \mathrm{~h}$ at 37 and $40.5^{\circ} \mathrm{C}$ to $\mathrm{MC}, 4-\mathrm{CMC}$, and 4-MMC (1000 $\left.\mu \mathrm{M}\right)$ showed an accumulation of AO dye within acidic compartments (Figure 7A). All the tested drugs increased the formation and size of the AVOs at both temperature conditions. Moreover, 4-CMC and 4-MMC at hyperthermic conditions affected the morphology of the cells, with a reduction of neuritic processes (Figure 7A). To confirm the effect of the investigated compounds on AVO formation, SH-SY5Y cells were exposed for $24 \mathrm{~h}$ at 37 and $40.5^{\circ} \mathrm{C}$ to MC and 4-MMC (1000 and $2000 \mu \mathrm{M})$ and to 4-CMC (500 and $1000 \mu \mathrm{M})$ and AVOs were quantified by flow cytometry (Figure 7B). At $37^{\circ} \mathrm{C}, 4-\mathrm{CMC}$ and 4 -MMC showed a significantly increased percentage of $\mathrm{AO}+$ cells at $1000 \mu \mathrm{M}$ compared to control incubations. Compared to $37^{\circ} \mathrm{C}$, exposure to 4 - $\mathrm{CMC}$ and $4-\mathrm{MMC}$ at $40.5^{\circ} \mathrm{C}$ was associated with more AVO formation (Figure 7B), and 4-CMC significantly increased AVO abundance at $40.5^{\circ} \mathrm{C}$ already at $500 \mu \mathrm{M}$.
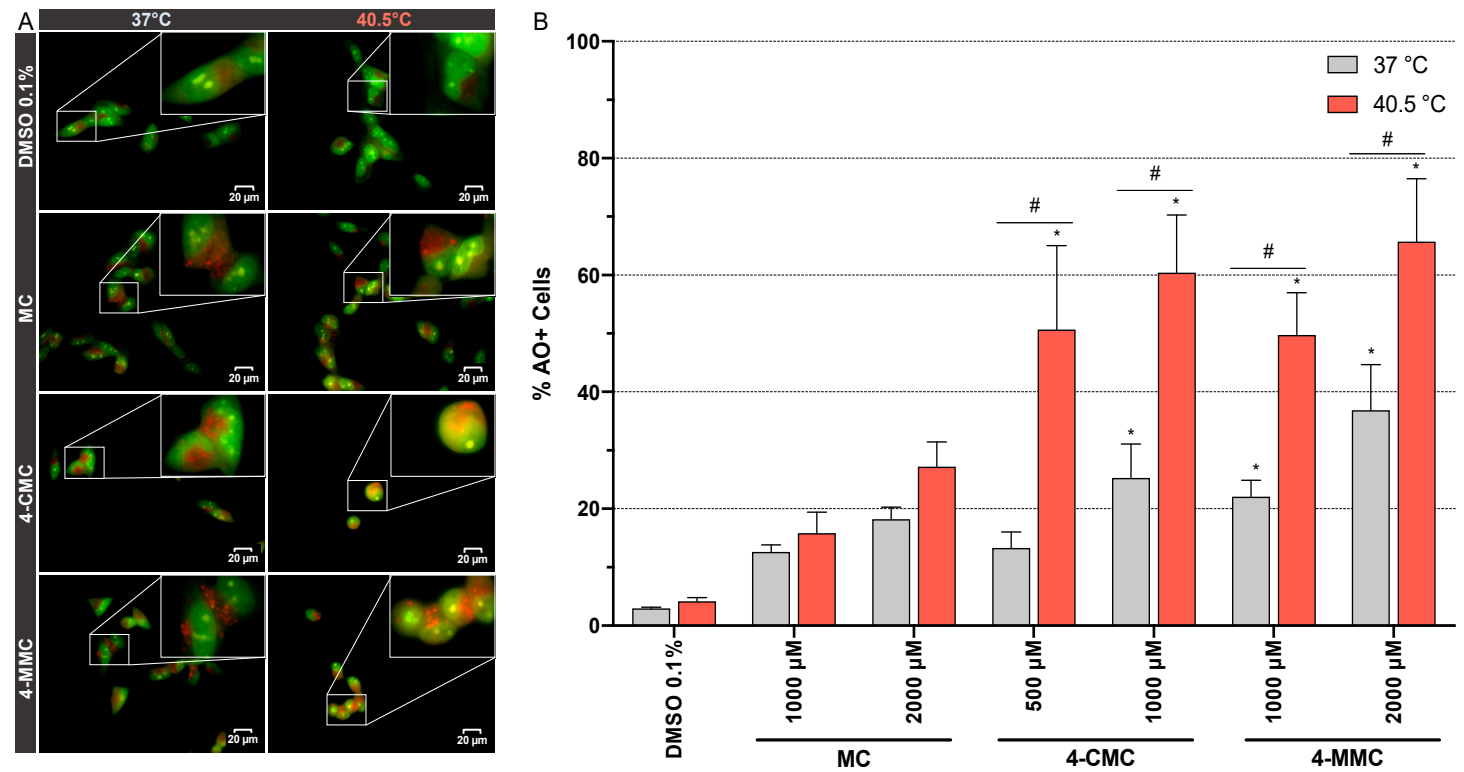

Figure 7. (A) Fluorescence microscopy visualization of acidic vesicular organelles (AVOs) stained with acridine orange (AO). SH-SY5Y cells were exposed to MC, 4-CMC, and 4-MMC (1000 $\mu \mathrm{M})$ for $24 \mathrm{~h}$ at 37 and $40.5^{\circ} \mathrm{C}$. Scale bar $20 \mu \mathrm{m}$, magnification $60 \times$. (B) Flow cytometric quantification of AVOs. SH-SY5Y cells were exposed to MC (1000 and $2000 \mu \mathrm{M}), 4-\mathrm{CMC}(500$ and $1000 \mu \mathrm{M})$, and 4-MMC (1000 and $2000 \mu \mathrm{M})$ for $24 \mathrm{~h}$ at 37 and $40.5{ }^{\circ} \mathrm{C}$. Data are expressed as mean \pm SEM of five independent experiments. Statistical comparisons were performed with one-way ANOVA followed by $t$-tests $\left({ }^{*} P \leq 0.05\right.$ versus control at the same temperature; ${ }^{\#} P \leq 0.05$ versus the same concentration at a different temperature). 


\section{Discussion}

Barbosa et al. [17] have shown in a previous study that the toxicity of ecstasy and ecstasy metabolites on differentiated SH-SY5Y cells is increased at hyperthermic $\left(40^{\circ} \mathrm{C}\right)$ compared to normothermic $\left(37^{\circ} \mathrm{C}\right)$ conditions. Similarly, in the present study, we demonstrated that hyperthermic conditions increase the cytotoxicity of methcathinones by inducing apoptotic and necrotic cell death. The loss in cell membrane integrity was preceded by a decrease in cellular ATP content, a typical feature of mitochondrial toxicants [21,35]. We could confirm our previous investigations on the hepatocellular and muscle toxicity observed with these drugs $[27,36]$.

The choice of the higher temperature was based on the study of Barbosa et al. [17] and on clinical reports suggesting that body temperatures $\geq 40^{\circ} \mathrm{C}$ are associated with severe complications, such as intravascular coagulation, rhabdomyolysis, renal and multiorgan failure, and even death, in patients having ingested ecstasy or other psychostimulants $[9,10]$.

The mitochondrial toxicity of the methcathinones studied was confirmed by the investigation of their effect on mitochondrial respiration. For all compounds studied, a prominent reduction of basal and FCCP-induced respiration was observed at $40.5^{\circ} \mathrm{C}$ compared to $37^{\circ} \mathrm{C}$. Mitochondrial toxicants that reduce the OCR, which indicates an impairment of the electron transport chain, can result in a decrease in $\Delta \psi \mathrm{m}$ and an increase in mitochondrial generation of ROS [37], which we observed in the current study. In agreement with the results of the current study, previous in vitro investigations have shown that synthetic methcathinones increase the production of ROS and nitrogen reactive species in human dopaminergic SH-SY5Y cells [25]. Moreover, animal studies revealed that methcathinones increase the expression of the antioxidant enzymes superoxide dismutase, catalase, and glutathione peroxidase in response to ROS accumulation [38].

Mitochondrial impairment and ROS accumulation can lead to the opening of the mitochondrial permeability transition pore (mPTP), and subsequently to the release of cytochrome $c$ into the cytoplasm, which is followed by caspase activation and apoptosis [39,40]. In our study, exposure to 4-CMC and 4-MMC already induced apoptosis and/or necrosis at both temperature conditions after $6 \mathrm{~h}$ of incubation.

Surprisingly, after $6 \mathrm{~h}$ of incubation, the compounds investigated were more toxic at normothermic conditions than under hyperthermic conditions, whereas, after $24 \mathrm{~h}$, the temperature shift from 37 to $40.5^{\circ} \mathrm{C}$ clearly increased the toxicity of the methcathinones studied. These findings suggested the induction of defensive mechanisms that could protect the cells during the first hours of the caloric insult. We therefore determined the expression of Hsp70 proteins, which are molecular chaperones synthesized in response to a heat shock [41]. As shown in Figure 5, hyperthermic conditions increased the expression of Hsp70 proteins, independently of the exposure to the compounds tested. Already after $6 \mathrm{~h}$ at $40.5^{\circ} \mathrm{C}$, the expression of Hsp70 was significantly higher than under normothermic conditions. These proteins, which assist in the folding and assembly of newly synthesized proteins as well as refolding of misfolded and aggregated proteins, act in an ATP-controlled fashion [42]. Importantly, Hsp70 proteins can inhibit mitochondrial cytochrome $c$ release, apoptosome formation, and caspase activation $[43,44]$. The results of the current study suggest that at the 6-h time point, the induction of HSP70 partially prevented not only the cellular damage induced by heat but also the toxic insult by the methcathinones investigated.

However, because of the ongoing ROS-induced protein and organelle damage and the associated decrease in the cellular ATP content, this defensive system may be not able to counteract the cellular insults. Autophagy is an additional defensive mechanism, which may be stimulated under these conditions. In support of this assumption, it has been shown that 3-fluoromethcathinone (3-FMC), another synthetic methcathinone, activates autophagy in the neuronal cell line HT22 [45]. Autophagy is an evolutionarily conserved process, which plays a pivotal role in maintaining the viability of eukaryotic organisms by regulating the intracellular balance between anabolism and catabolism [46]. Autophagy is activated as a protective mechanism when cells are not able to respond to nutrient stress, the accumulation of misfolded proteins, and/or organelle damage [47]. In our investigations, LC3 II, 
an early marker of autophagy [48], was overexpressed in SH-SY5Y cells after exposure to 4-CMC under both temperature conditions. Furthermore, we demonstrated the stimulation of autophagy directly by the visualization of acidic vesicular organelles (AVOs) in SH-SY5Y cells exposed to 4-CMC and 4-MMC, which is a marker of late autophagy. Similar to the induction of HSP70, hyperthermic conditions also increased the formation of AVOs, suggesting that the activation of the cellular defense systems is tightly coordinated.

In comparison to their pharmacological activity, which is observed in the high nanomolar to micromolar range depending on the compound and the pharmacological effect considered [49], cytotoxicity was detected at higher concentrations in the current study. For 4-CMC, blood concentrations reached approximately 1 micromolar with non-toxic pharmacological doses and up to 10 micromolar in patients with intoxications [50]. In the current study, we started to see an impairment of cellular oxygen uptake at 200 micromolar for MC, 4-CMC, and 4-MMC. A possible explanation for this discrepancy between pharmacological activity and in vitro toxicity may be that the cell lines used in the current study may be less sensitive to toxicants than primary cells. This has, for instance, been shown for hepatotoxicants, which are typically less toxic for human hepatocyte cell lines than for primary human hepatocytes [51,52]. Furthermore, patients presenting with neurotoxicity have usually ingested doses higher than the pharmacological doses of these compounds and may have ingested additional toxic drugs and/or alcohol. Finally, the brain/plasma concentration ratio for 4-MMC is $>1$, indicating that the drug penetrates the blood-brain barrier easily and that the concentration reached in the brain is higher than in plasma [53].

Interestingly, many studies have shown a link between autophagy and neurodegenerative diseases [31,54,55]. A prevalent pathological feature of many neurodegenerative diseases, such as Alzheimer's disease (AD), Parkinson's disease (PD), and Huntington disease (HD), is in fact the aggregation of misfolded proteins, which may result from the production of defective proteins and/or impaired function of the protein quality control systems. Our studies suggest that repetitive ingestion of neurotoxic drugs, such as methcathinones, and other neurotoxic neurostimulants may aggravate or even provoke such conditions.

\section{Conclusions}

In conclusion, 4-CMC and 4-MMC are mitochondrial toxicants whose toxicity is increased by shifting the temperature from 37 to $40.5^{\circ} \mathrm{C}$. SH-SY5Y cells exposed to $40.5^{\circ} \mathrm{C}$ activate cellular defense mechanisms, such as the expression of Hsp70 proteins, which can partially prevent early apoptosis and necrosis. With time, the activation of additional defense mechanisms, such as autophagy, is necessary to prevent cell dysfunction and cell death. Mitochondrial toxicity, which is accentuated by hyperthermia, represents an important mechanism of the neural toxicity of these compounds.

Supplementary Materials: The following are available online at http://www.mdpi.com/2073-4409/9/4/965/s1, Figure S1: Chemical structures of amphetamine and methcathinone derivatives, Figure S2: Plasma membrane integrity and intracellular ATP content of SH-SY5Y cells exposed to amphetamine and amphetamine derivatives, Figure S3: Mitochondrial membrane potential in SH-SY5YX cells exposed to methcathinone derivatives, Figure S4: Percentage of viable, necrotic and apoptotic cells after $24 \mathrm{~h}$ of exposure to methcathinone derivatives, Figure S5: Plasma membrane integrity and intracellular ATP content of SH-SY5Y cells exposed for $6 \mathrm{~h}$ to methcathinone derivatives, Table S1: IC $_{50}$ values of membrane toxicity and ATP depletion of SH-SY5Y cells exposed to methcathinone derivatives.

Author Contributions: Study design: X.Z., R.V.M., S.K.; experiments: X.Z., J.B., R.V.M.; data interpretation: X.Z., J.B., R.V.M., S.K.; writing-original draft preparation: X.Z., J.B., R.V.M.; writing-review and editing: J.B., R.V.M., M.E.L., S.K.; funding acquisition: X.Z., S.K. All authors have read and agreed to the published version of the manuscript.

Funding: The research was funded by a grant from the Swiss National Science Foundation to S.K. (SNF 31003A_156270). X.Z. is a recipient of China Scholarship Council Stipendium of the P.R. China.

Conflicts of Interest: The authors declare no conflict of interest. 


\section{References}

1. Smith, J.P.; Sutcliffe, O.B.; Banks, C.E. An overview of recent developments in the analytical detection of new psychoactive substances (NPSs). Analyst 2015, 140, 4932-4948. [CrossRef]

2. Madras, B.K. The Growing Problem of New Psychoactive Substances (NPS). Curr. Top. Behav. Neurosci. 2017, 32, 1-18. [PubMed]

3. Valente, M.J.; Guedes de Pinho, P.; de Lourdes Bastos, M.; Carvalho, F.; Carvalho, M. Khat and synthetic cathinones: A review. Arch. Toxicol. 2014, 88, 15-45. [CrossRef]

4. Taschwer, M.; Wei $\beta$, J.A.; Kunert, O.; Schmid, M.G. Analysis and characterization of the novel psychoactive drug 4-chloromethcathinone (clephedrone). Forensic Sci. Int. 2014, 244, e56-e59. [CrossRef]

5. Griffiths, P.; Lopez, D.; Sedefov, R.; Gallegos, A.; Hughes, B.; Noor, A.; Royuela, L. Khat use and monitoring drug use in Europe: The current situation and issues for the future. J. Ethnopharmacol. 2010, 132, 578-583. [CrossRef] [PubMed]

6. Schifano, F.; Napoletano, F.; Arillotta, D.; Zangani, C.; Gilgar, L.; Guirguis, A.; Corkery, J.M.; Vento, A. The clinical challenges of synthetic cathinones. Br. J. Clin. Pharmacol. 2019, 86, 410-419. [CrossRef] [PubMed]

7. Prosser, J.M.; Nelson, L.S. The toxicology of bath salts: A review of synthetic cathinones. J. Med. Toxicol. 2012, 8, 33-42. [CrossRef] [PubMed]

8. Paillet-Loilier, M.; Cesbron, A.; Le Boisselier, R.; Bourgine, J.; Debruyne, D. Emerging drugs of abuse: Current perspectives on substituted cathinones. Subst. Abuse Rehabil. 2014, 5, 37-52. [PubMed]

9. Liechti, M.E. Effects of MDMA on body temperature in humans. Temperature 2014, 1, 192-200. [CrossRef]

10. Callaway, C.W.; Clark, R.F. Hyperthermia in psychostimulant overdose. Ann. Emerg. Med. 1994, $24,68-76$. [CrossRef]

11. Halpern, P.; Moskovich, J.; Avrahami, B.; Bentur, Y.; Soffer, D.; Peleg, K. Morbidity associated with MDMA (ecstasy) abuse: A survey of emergency department admissions. Hum. Exp. Toxicol. 2011, 30, $259-266$. [CrossRef]

12. Zaami, S.; Giorgetti, R.; Pichini, S.; Pantano, F.; Marinelli, E.; Busardò, F.P. Synthetic cathinones related fatalities: An update. Eur. Rev. Med. Pharmacol. Sci. 2018, 22, 268-274. [PubMed]

13. Angoa-Pérez, M.; Anneken, J.H.; Kuhn, D.M. Neurotoxicology of synthetic cathinone analogs. Curr. Top. Behav. Neurosci. 2017, 32, 209-230.

14. Camilleri, A.M.; Caldicott, D. Underground pill testing, down under. Forensic Sci. Int. 2005, 151, 53-58. [CrossRef]

15. Parrott, A.C. MDMA (3, 4-Methylenedioxymethamphetamine) or ecstasy: The neuropsychobiological implications of taking it at dances and raves. Neuropsychobiology 2004, 50, 329-335. [CrossRef] [PubMed]

16. Parrott, A.C.; Rodgers, J.; Buchanan, T.; Ling, J.; Heffernan, T.; Scholey, A.B. Dancing hot on Ecstasy: Physical activity and thermal comfort ratings are associated with the memory and other psychobiological problems reported by recreational MDMA users. Hum. Psychopharmacol. 2006, 21, 285-298. [CrossRef] [PubMed]

17. Barbosa, D.J.; Capela, J.P.; Silva, R.; Ferreira, L.M.; Branco, P.S.; Fernandes, E.; Bastos, M.L.; Carvalho, F. "Ecstasy"-induced toxicity in SH-SY5Y differentiated cells: Role of hyperthermia and metabolites. Arch Toxicol. 2014, 88, 515-531. [CrossRef]

18. Kovalevich, J.; Langford, D. Considerations for the use of SH-SY5Y neuroblastoma cells in neurobiology. Methods Mol. Biol. 2013, 1078, 9-21.

19. Kysenius, K.; Brunello, C.A.; Huttunen, H.J. Mitochondria and NMDA receptor-dependent toxicity of berberine sensitizes neurons to glutamate and rotenone injury. PLoS One 2014, 9, e107129. [CrossRef]

20. Song, M.S.; Ryu, P.D.; Lee, S.Y. Kv3.4 is modulated by HIF-1 $\alpha$ to protect SH-SY5Y cells against oxidative stress-induced neural cell death. Sci. Rep. 2017, 7, 2075. [CrossRef]

21. Felser, A.; Blum, K.; Lindinger, P.W.; Bouitbir, J.; Krähenbühl, S. Mechanisms of hepatocellular toxicity associated with dronedarone-a comparison to amiodarone. Toxicol. Sci. 2013, 131, 480-490. [CrossRef] [PubMed]

22. Wang, C.-M.; Yang, C.-Q.; Cheng, B.-H.; Chen, J.; Bai, B. Orexin-A protects SH-SY5Y cells against $\mathrm{H} 2 \mathrm{O} 2$-induced oxidative damage via the PI3K/MEK1/2/ERK1/2 signaling pathway. Int. J. Immunopathol. Pharmacol. 2018, 32, 2058738418785739. [CrossRef] 
23. Ferlemann, F.C.; Menon, V.; Condurat, L.; Rössler, J. Surface marker profiling of SH-SY5Y cells enables small molecule screens identifying BMP4 as a modulator of neuroblastoma differentiation. Sci. Rep. $2017,7$. [CrossRef] [PubMed]

24. Yano, K.; Yanagisawa, T.; Mukae, K.; Niwa, Y.; Inoue, Y.; Moriyasu, Y. Dissection of autophagy in tobacco BY-2 cells under sucrose starvation conditions using the vacuolar H+-ATPase inhibitor concanamycin A and the autophagy-related protein Atg8. Plant Signal Behav. 2015, 10, e1082699. [CrossRef] [PubMed]

25. Valente, M.J.; Amaral, C.; Correia-da-Silva, G.; Duarte, H.A. Methylone and MDPV activate autophagy in human dopaminergic SH-SY5Y cells: A new insight into the context of $\beta$-keto amphetamines-related neurotoxicity. Arch. Toxicol. 2017, 91, 3663-3676. [CrossRef] [PubMed]

26. Thomé, M.P.; Filippi-Chiela, E.C.; Villodre, E.S.; Migliavaca, C.B.; Onzi, G.R.; Felipe, K.B.; Lenz, G. Ratiometric analysis of Acridine Orange staining in the study of acidic organelles and autophagy. J.Cell Sci. 2016, 129, 4622-4632. [CrossRef]

27. Zhou, X.; Luethi, D.; Sanvee, G.M.; Bouitbir, J.; Liechti, M.E.; Krähenbühl, S. Molecular Toxicological Mechanisms of Synthetic Cathinones on C2C12 Myoblasts. Int. J. Mol. Sci. 2019, 20, 1561. [CrossRef]

28. Wang, Y.; Nartiss, Y.; Steipe, B.; McQuibban, G.A.; Kim, P.K. ROS-induced mitochondrial depolarization initiates PARK2/PARKIN-dependent mitochondrial degradation by autophagy. Autophagy 2012, 8, 1462-1476. [CrossRef]

29. Eguchi, Y.; Shimizu, S.; Tsujimoto, Y. Intracellular ATP levels determine cell death fate by apoptosis or necrosis. Cancer Res. 1997, 57, 1835-1840.

30. Sharma, D.; Masison, D.C. Hsp70 structure, function, regulation and influence on yeast prions. Protein Pept. Lett. 2009, 16, 571-581. [CrossRef]

31. Guo, F.; Liu, X.; Cai, H.; Le, W. Autophagy in neurodegenerative diseases: Pathogenesis and therapy. Brain Pathol. 2018, 28, 3-13. [CrossRef]

32. Katschinski, D.M.; Boos, K.; Schindler, S.G.; Fandrey, J. Pivotal role of reactive oxygen species as intracellular mediators of hyperthermia-induced apoptosis. J. Biolog. Chem. 2000, 275, 21094-21098. [CrossRef] [PubMed]

33. Kuma, A.; Matsui, M.; Mizushima, N. LC3, an autophagosome marker, can be incorporated into protein aggregates independent of autophagy: Caution in the interpretation of LC3 localization. Autophagy 2007, 3, 323-328. [CrossRef]

34. Tanida, I.; Ueno, T.; Kominami, E. LC3 and Autophagy. Methods Mol. Biol. 2008, 445, 77-88. [PubMed]

35. Fromenty, B.; Fisch, C.; Berson, A.; Letteron, P.; Larrey, D.; Pessayre, D. Dual effect of amiodarone on mitochondrial respiration. Initial protonophoric uncoupling effect followed by inhibition of the respiratory chain at the levels of complex I and complex II. J. Pharmacol. Exp. Ther. 1990, 255, 1377-1384. [PubMed]

36. Luethi, D.; Liechti, M.E.; Krähenbühl, S. Mechanisms of hepatocellular toxicity associated with new psychoactive synthetic cathinones. Toxicology 2017, 387, 57-66. [CrossRef] [PubMed]

37. Bae, Y.S.; Oh, H.; Rhee, S.G.; Yoo, Y.D. Regulation of reactive oxygen species generation in cell signaling. Mol. Cells 2011, 32, 491-509. [CrossRef] [PubMed]

38. López-Arnau, R.; Martinez-Clemente, J.; Rodrigo, T.; Pubill, D.; Camarasa, J.; Escubendo, E. Neuronal changes and oxidative stress in adolescent rats after repeated exposure to mephedrone. Toxicol. Appl. Pharmacol. 2015, 286, 27-35. [CrossRef]

39. Liu, X.; Kim, C.N.; Yang, J.; Jemmerson, R.; Wang, X. Induction of apoptotic program in cell-free extracts:Requirement for datp and cytochrome c. Cell 1996, 86, 147-157. [CrossRef]

40. Green, D.R.; Reed, J.C. Mitochondria and apoptosis. Science 1998, 281, 1309-1312. [CrossRef]

41. He, Z.; Sun, X.; Ma, Z.; Fu, J.; Huang, B.; Liu, F.; Chen, Y.; Deng, T.; Han, X.; Sun, D. Heat shock protein 70 protects mouse against post-infection irritable bowel syndrome via up-regulating intestinal gammadelta T cell's Th17 response. Cell Biosci. 2018, 8, 38. [CrossRef] [PubMed]

42. Mayer, M.; Bukau, B. Hsp70 chaperones: Cellular functions and molecular mechanism. Cell. Mol. Life Sci. 2005, 62, 670. [CrossRef]

43. Stankiewicz, A.R.; Lachapelle, G.; Foo, C.P.; Radicioni, S.M.; Mosser, D.D. Hsp70 inhibits heat-induced apoptosis upstream of mitochondria by preventing Bax translocation. J. Biol. Chem. 2005, 280, 38729-38739. [CrossRef] [PubMed]

44. Li, C.Y.; Lee, J.S.; Ko, Y.G.; Kim, J.I.; Seo, J.S. Heat shock protein 70 inhibits apoptosis downstream of cytochrome c release and upstream of caspase-3 activation. J. Biol. Chem. 2000, 275, 25665-25671. [CrossRef] [PubMed] 
45. Siedlecka-Kroplewska, K.; Wrońska, A.; Stasiłojć, G.; Kmieć, Z. The designer drug 3-fluoromethcathinone induces oxidative stress and activates autophagy in HT22 neuronal cells. Neurotox Res. 2018, 34, 388-400. [CrossRef] [PubMed]

46. Khandia, R.; Dadar, M.; Munjal, A.; Dhama, K.; Karthik, K.; Tiwari, R.; Yatoo, M.I.; Iqbal, H.M.N.; Pal Singh, K.; Joshi, S.K.; et al. A comprehensive review of autophagy and its various roles in infectious, non-infectious, and lifestyle diseases: Current knowledge and prospects for disease prevention, novel drug design, and therapy. Cells 2019, 8, 674. [CrossRef] [PubMed]

47. Kroemer, G.; Levine, B. Autophagic cell death: The story of a misnomer. Nat. Rev. Mol Cell Biol. 2008, 9, 1004-1010. [CrossRef]

48. Tanida, I.; Minematsu-Ikeguchi, N.; Ueno, T.; Kominami, E. Lysosomal turnover, but not a cellular level, of endogenous LC3 is a marker for autophagy. Autophagy 2005, 1, 84-91. [CrossRef]

49. Luethi, D.; Walter, W.; Zhou, X.; Rudin, D.; Krähenbühl, S.; Liechti, M.E. Para-Halogenation Affects Monoamine Transporter Inhibition Properties and Hepatocellular Toxicity of Amphetamines and Methcathinones. Front. Pharmacol. 2019, 10, 438. [CrossRef]

50. Tomczak, E.; Woźniak, M.K.; Kata, M.; Wiergowski, M.; Szpiech, B.; Biziuk, M. Blood concentrations of a new psychoactive substance 4-chloromethcathinone (4-CMC) determined in 15 forensic cases. Forensic Toxicol. 2018, 36, 476-485. [CrossRef]

51. Berger, B.; Donzelli, M.; Maseneni, S.; Boess, F.; Roth, A.; Krähenbühl, S.; Haschke, M. Comparison of Liver Cell Models Using the Basel Phenotyping Cocktail. Front. Pharmacol. 2016, 7, 443. [CrossRef] [PubMed]

52. Gerets, H.H.; Tilmant, K.; Gerin, B.; Chanteux, H.; Depelchin, B.O.; Dhalluin, S.; Atienzar, F.A. Characterization of primary human hepatocytes, HepG2 cells, and HepaRG cells at the mRNA level and CYP activity in response to inducers and their predictivity for the detection of human hepatotoxins. Cell. Biol. Toxicol. 2012, 28, 69-87. [CrossRef]

53. Calinski, D.M.; Kisor, D.F.; Sprague, J.E. A review of the influence of functional group modifications to the core scaffold of synthetic cathinones on drug pharmacokinetics. Psychopharmacology (Berl) 2019, 236, 881-890. [CrossRef]

54. Turturici, G.; Sconzo, G.; Geraci, F. Hsp70 and its molecular role in nervous system diseases. Biochem. Res. Int. 2011, 2011, 618127. [CrossRef] [PubMed]

55. Penke, B.; Bogár, F.; Crul, T.; Sántha, M.; Tóth, M.E.; Vígh, L. Heat shock proteins and autophagy pathways in neuroprotection: From molecular bases to pharmacological interventions. Int. J. Mol. Sci. 2018, 19, 325. [CrossRef] [PubMed]

(C) 2020 by the authors. Licensee MDPI, Basel, Switzerland. This article is an open access article distributed under the terms and conditions of the Creative Commons Attribution (CC BY) license (http://creativecommons.org/licenses/by/4.0/). 